\title{
ECONOMIC LITERACY: A CROSS-SECTIONAL STUDY IN PORTUGUESE UNDERGRADUATE STUDENTS
}

\section{MARIA ISABEL RIBEIRO \& ANTÓNIO FERNANDES}

Institute Polytechnic of Bragança, Campus de Santa Apolónia, 5300-253, Bragança, Portugal

\section{Introduction}

The economy is linked to the essentials of each individual's life. Knowledge about the economy and its functioning is fundamental to make informed decisions within the various roles that each individual plays in society, whether as consumer, seller, producer, investor, worker or even as a citizen [1]. Economic literacy also has long-term consequences on the stability of the economy as a whole [2]. Understanding the functioning of markets enables individuals to evaluate policy decisions and their consequences as well as make better decisions that maximize their quality of life and well-being [3]. It is understood by economic literacy the knowledge and skills that allow the improvement of personal and social decisions on various economic problems encountered in daily life [4].

\section{Objectives}

To evaluate undergraduate students' knowledge on economics and to analyse their ability to understand basic economic concepts.

\section{Methodology}

To achieve these objectives, an observational, quantitative, analytical and crosssectional study was carried out. To collect the data, it was applied questionnaire that included socioeconomic variables and the Standards in Economics Survey (SES) developed by the National Council of Economic Education better known as Economic Literacy Test (ELT). This test includes twenty questions of multiple choice. There were four choices: a correct one, two incorrect answers and a 4th choice for the students that did not knew the answer. Basically, the ELT is about basic economic concepts and allows evaluating the literacy of students and adults in four issues, namely consumer economics, production economics; financial economics, government's economic role, and international trade. The ELT was applied to all students enrolled in the General Economics Principles (GEP) curricular unit, which were present in the first class, in the second half of September 2017. GEP is a curricular unit of the Languages for International Relations degree from a public higher education institution, located in the northern interior of Portugal. Of the 95 students enrolled in GEP, 70 completed the questionnaire obtaining a $73.7 \%$ response rate. Data analysis was carried out using IBM SPSS (Statistical Package for Social Sciences) 23.0 Descriptive statistics was used to characterize the sample. In order to compare the students' Knowledge level on economics considering previous training, the Mann-Whitney test was applied at a significance level of $5 \%$

\section{Results}

Students were, mainly, female (62.9\%), with a mean age of 19.75 years old (SD = 2.31), $20.0 \%$ had already previous training in economics during secondary education and $14.3 \%$ have already attended to the GEP curricular unit in previous years without success. Most students came from rural areas (53.0\%) and had active parents (father: $84.8 \%$; mother: $71.4 \%$ ) that earned a monthly income level that ranged from 501 to 1000 Euros (46.4\%). Most mothers had an educational level between 3th cycle (28.4\%) and secondary education (35.7\%) while father's educational level ranged between 2 nd and 3 th cycles $(22.4 \%$ and $28.4 \%$, respectively), as shown in Table 1.

\begin{tabular}{|c|c|c|c|}
\hline Variable & Categories & $\mathrm{n}$ & $\%$ \\
\hline \multirow{2}{*}{$\begin{array}{l}\text { Previous training on economics during high school } \\
(\mathrm{N}=69)\end{array}$} & No & 56 & 80,0 \\
\hline & Yes & 13 & 20.0 \\
\hline \multirow{2}{*}{$\begin{array}{l}\text { Previous training on General Economics Principles } \\
(\mathrm{N}=69)\end{array}$} & No & 60 & 85.7 \\
\hline & Yes & 9 & 14.3 \\
\hline \multirow{2}{*}{$\begin{array}{l}\mathrm{Sex} \\
(\mathrm{N}=69)\end{array}$} & Male & 25 & 36.2 \\
\hline & Female & 44 & 62.9 \\
\hline \multirow{3}{*}{$\begin{array}{l}\text { Father's professional situation } \\
(\mathrm{N}=66)\end{array}$} & Active & 56 & 84.8 \\
\hline & Unemployed & 3 & 4.5 \\
\hline & Retired or handicapped & 7 & 10.6 \\
\hline \multirow{4}{*}{$\begin{array}{l}\text { Mother's professional si } \\
(\mathrm{N}=70)\end{array}$} & Active & 50 & 71.4 \\
\hline & Unemployed & 9 & 12.9 \\
\hline & Retired or handicapped & 1 & 1.4 \\
\hline & Domestic & 10 & 14.3 \\
\hline \multirow{5}{*}{$\begin{array}{l}\text { Father's educational le } \\
(\mathrm{N}=67)\end{array}$} & $1^{\text {st }}$ cycle & 12 & 17.9 \\
\hline & $2^{\text {nd }}$ cycle & 16 & 22.4 \\
\hline & 3th cycle & 19 & 28.4 \\
\hline & Secondary education & 12 & 17.9 \\
\hline & Higher education & 9 & 13.4 \\
\hline \multirow{5}{*}{$\begin{array}{l}\text { Mother's educational level } \\
(\mathrm{N}=70)\end{array}$} & $1^{\text {st }}$ cycle & 6 & 8.6 \\
\hline & $2^{\text {nd }}$ cycle & 11 & 15.7 \\
\hline & 3th cycle & 19 & 27.1 \\
\hline & Secondary education & 25 & 35.7 \\
\hline & Higher education & 9 & 12.9 \\
\hline \multirow{5}{*}{$\begin{array}{l}\text { Monthly income level } \\
(\mathrm{N}=69)\end{array}$} & Less than 500 Euros & 11 & 15.9 \\
\hline & 501 to 1000 euros & 32 & 46.4 \\
\hline & 1001 to 1500 Euros & 16 & 23.2 \\
\hline & 1501 to 2000 Euros & 6 & 8.7 \\
\hline & More than 2000 Euros & 4 & 5.8 \\
\hline \multirow{2}{*}{$\begin{array}{l}\text { Residence } \\
(\mathrm{N}=66)\end{array}$} & Rural & 35 & 53.0 \\
\hline & Urban & 31 & 47.0 \\
\hline
\end{tabular}

The knowledge level was, on average, 12.46 (SD = 2.783) out of 20. The percentage of correct answers was, on average, 62.3\%. As shown in Figure 1, the distribution of students by level of knowledge was as follows: poor (14.3\%); fair $(44.3 \%)$ good $(40 \%)$ and very good $(1.4 \%)$. Student's previous training in economics during secondary education ( $p$-value $=0.438$ ) and previous training in GEP ( $p$-value $=0.218$ ) did not prove to be differentiator factors of the knowledge level on economic issues (Table 2 ).

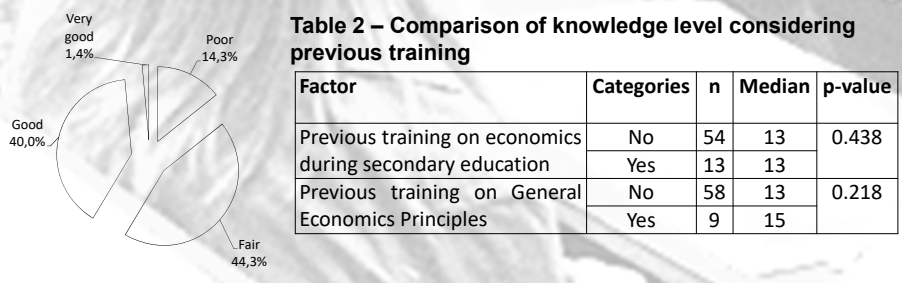

Figure 1 - Distribution of Students by knowledge leve

\section{Conclusion}

Students had a fair knowledge level on economics but they performed better on microeconomic issues related to consumer behavior. They performed worse on macroeconomic issues related to the government role and inflation. Therefore, further research will involve the application of the ELT, in the first and last class, to all students enrolled in the GEP curricular unit. The aim is to examine the contribution of GEP to the student's economic literacy, specifically, on macroeconomic issues like government's economic role and inflation.

ACKNOWLEDGEMENTS

This work is supported by: the European Structural and Investment Funds in the FEDER component, through the Operational REFERENCES

(1) Varum, C.; Santos, E. \& Afreixo, V. (2014). Re [2] Jappelli, T. (2010). Economic Literacy: An International Comparison. CFS Working Paper No. 2010/16. Center for Financial Studies.
[3] Koshal, R., Gupta, A., Goyal, A., \& Choudhary, V. (2008). Assessing Economic Literacy of Indian MBA Students. American Journal of Business, $23(2), 43-51$. 4] Grol, R., Sent, E. M., \& de Vries, B. (2017). Participate or observe? Effects of elo teracy. European Journal of Psychology of Education, 32 (2): 289-310. 